\title{
Site fidelity, homing and spawning migrations of flounder Platichthys flesus in the Tamar estuary, South West England
}

\author{
P. R. Dando* \\ Marine Biological Association of the UK, Citadel Hill, Plymouth PL1 2PB, UK
}

\begin{abstract}
Brand-marked flounder Platichthys flesus (L.) were used to study migrations, site fidelity and homing ability of individuals in the Tamar estuary, SW England, between 1976 and 1980. A total of 1308 recaptures were made, of 7401 flounder marked at 13 stations along a $29 \mathrm{~km}$ length of the estuary and 2 stations in Plymouth Sound. A further 1667 fish were marked on the spawning grounds in 1976, 57 being recaptured. Recaptured fish were released again, with individuals being recaptured on up to 6 occasions. In all but 118 cases, the recaptures within the estuary or Plymouth Sound were from the original capture sites, despite the displacement of 681 fish, after marking, to a variety of locations. Most flounder in the middle estuary did not move $>200 \mathrm{~m}$ along the estuary until they left to spawn. Flounder in the upper estuary also showed high site fidelity, but were temporarily displaced by adverse conditions such as river spates. Ripe, estuary-marked flounder were recaptured at sea from 10 to $35 \mathrm{~km}$ west of Plymouth in water depths of 35 to $55 \mathrm{~m}$. Most individuals returned to their original estuarine range after spawning. Twelve percent failed to return to the Tamar postspawning, all migrating eastwards. A total of 200 Tamar fish were released $200 \mathrm{~km}$ eastwards along the coast. Many of these migrated towards Plymouth, 2 reaching the estuary, although some returned to the release site post-spawning. The results are applicable to the management of flounder stocks and of estuaries, emphasising the value of retaining intertidal mud flats in estuary development plans.
\end{abstract}

KEY WORDS: Platichthys flesus · Flounder · Site fidelity · Tamar estuary · Marking · Migration · English Channel

Resale or republication not permitted without written consent of the publisher

\section{INTRODUCTION}

The flounder Platichthys flesus (L.) is a sea-spawning flatfish that is found along European coasts from the White Sea to the Mediterranean and Black Seas and is fished commercially (Norman 1934, Wheeler 1978, Maitland \& Herdson 2009). It penetrates further into fresh water in cooler northern waters (Maitland \& Herdson 2009). Flounders in southern England and on the eastern side of the North Sea spend most of their lives in estuaries, penetrating into rivers where there are no barriers to migration (Wheeler 1979, Beaumont \& Mann 1984, Kerstan 1991, Hutchinson \& Hawkins 1993, Bos 1999). O-Group fish enter these estuaries and rivers as metamorphosing or newly metamor- phosed post-larvae during April to May (Möller \& Dieckwisch 1991, van der Veer et al. 1991, Hutchinson \& Hawkins 1993).

In the Plymouth area, flounders typically leave the estuaries in late January to February (Dando \& Ling 1980, Sims et al. 2004), returning subsequently to the estuaries. Metamorphosing young enter the estuaries in April and rapidly ascend to the freshwater zone (Dando 1984). Sims et al. (2004) found that the length of the spawning season is $28.1 \pm 19.8 \mathrm{~d}$ (mean $\pm \mathrm{SD}$ ). Thus, most adult flounder are confined to the estuaries for $\sim 11$ mo of the year in this area.

There have been few studies on the movements of individual Platichthys flesus over a prolonged period. Tagging studies have shown the movement of flounder 
from the estuaries to the sea in the winter, prior to spawning, with a return to the estuaries and rivers post-spawning (Hartley 1947, Summers 1979). Acoustic tag studies on a few individuals in the River Bann, Northern Ireland, showed that the fish moved $<400 \mathrm{~m}$ over a $12 \mathrm{~h}$ study period (Wirjoatmodjo \& Pitcher 1984). In the Tamar estuary (Fig. 1), which enters the English Channel at Plymouth, migrations of the flounder population were first studied by Hartley (1947). He marked 1039 fish from the Tamar and Lynher estuaries with Petersen discs during the winter of 1937/1938. Of the 155 recoveries obtained, 4 were from the sea.
Early studies on the genetics of flounder in the Tamar suggested that there might be a seasonal difference in allele ratios between fish in different areas of the estuary (Marine Biological Association of the United Kingdom 1973). Although sampling in later years did not replicate this, a marking study was started in January 1976 to investigate whether there was a segregation of flounder within the $30.5 \mathrm{~km}$ long Tamar estuary and on the spawning grounds. The results from this marking study, to test the hypothesis that individual flounder have a limited home range within the estuary, are presented here. An account of the differences in population sizes, feeding and growth rates of flounder in different regions of the estuary will be published separately.

\section{MATERIALS AND METHODS}

Study area and fishing grounds. The Tamar estuary is $30.5 \mathrm{~km}$ long, measured along the mid-line of the main channel shown on 1:10560 Ordnance Survey maps, from its mouth, at Plymouth Sound, to the weir at Gunnislake (Fig. 1c). Trawling stations along the Tamar are designated by $\mathrm{T}$ followed by a number representing the approximate distance in kilometres from the mouth, similarly along the Lynher, by L and a number. Stations in Plymouth Sound were similarly designated with $\mathrm{P}$ (Fig. 1b). Positions along the Tamar were determined from bearings to landmarks shown on the maps.

The lower $6 \mathrm{~km}$ of the estuary, the Hamoaze, receives water from 3 major rivers (Tamar, Lynher and Tavy). The

Fig. 1. Tamar estuary: (a) location in Europe; (b) positions of marking and release stations in Plymouth Sound, and the capture and release area for flounder Platichthys flesus marked on the spawning grounds (shaded), as well as the positions in which estuarymarked fish were caught during the spawning season; numbers refer to the estuary stations where the fish were marked; (c) the Tamar estuary system with distances in kilometres along the main channel from the mouth (marked by dashed lines). Trawling stations are indicated by $\mathrm{T}$ (Tamar) or $\mathrm{L}$ (Lynher) followed by the approximate distance from the estuary mouth in kilometres; the approximate areas trawled are shaded. This figure was reproduced in part from ordnance survey map data by permission of the Ordnance Survey (Crown copyright 2010) 
Naval Dockyard and moorings made the lower $7.5 \mathrm{~km}$ unsuitable for trawling, and the only trawling station in this section, T2, was off a large tidal inlet, $2 \mathrm{~km}$ from the mouth (Fig. 1c). Detailed descriptions of the estuary and the fauna are given by Percival (1929) and Hartley \& Spooner (1938). The middle reach of the estuary, 7 to $15 \mathrm{~km}$ from the mouth, is characterised by extensive intertidal mud flats and some long tidal creeks, or 'lakes'. On the Tamar itself, the lowest trawling stations were T8 and T9. Stn T9 was separated by a rock outcrop and a distance of $200 \mathrm{~m}$ from T10. There was another $200 \mathrm{~m}$ separating Stn T10 from T11. From Stn T12 onwards, all the trawling stations ran approximately along the mid-line of the channel. Flounder cannot penetrate above the weir. Above Stn T20, trawling was mainly undertaken on high-water spring (HWS) tides. Above $15 \mathrm{~km}$, the narrow nature of the estuary means that river spates frequently wash all fish out of the upper part of the estuary and, occasionally, as on 19 January 1977, hardly any fish were present above T11 due to the high river flow.

The narrow channel and shallow depth of the Tavy prevented trawling, although flounder penetrate to the tidal limit, $15 \mathrm{~km}$ from Plymouth Sound. Flounder movements in the Lynher were studied extensively by Hartley $(1940,1947)$ and were not further investigated, beyond 1 displacement of fish into the Lynher in a study of homing ability.

Other fishing activities in the estuary were low during the present study. Salmon seines were used, in season, between 12 and $22 \mathrm{~km}$ along the Tamar and in the Tavy estuary, and raised nets were used from flatboats (Hartley 1940) in the upper Lynher estuary. Some angling occurred, particularly at Stns P3, T8 and T16, and there was occasional fishing by stop-net in creeks off $\mathrm{T} 9$ and in the Tavy.

Fishing methods and marking. Flounder were captured using an otter trawl or 3 or $3.7 \mathrm{~m}$ beam trawls, fitted with $55 \mathrm{~mm}$ mesh nylon cod-ends, using a single tickler chain and tow times of $<15 \mathrm{~min}$. Tows were normally made within $2 \mathrm{~h}$ of low water at the lower and mid-estuary stations (T2 to T12) and within $2 \mathrm{~h}$ of high water at stations further up the estuary, where it was both narrower and shallower. Bottom and surface temperature and salinity measurements were made with an E. I. L. Model MC5 temperature/salinity meter. Water flow rates over Gunnilake Weir (30.5 km up-estuary) were provided by the Cornwall River Authority.

The total length, sex and state of maturity of the gonad, when it could be located by feel, or by shining a strong light through the fish, were recorded before marking the fish by freeze-branding (Dando \& Ling 1980). Flounder with a total length of $\geq 130 \mathrm{~mm}$ were used to provide sufficient space for the brands, although a few fish of 90 to $130 \mathrm{~mm}$ were marked with smaller brands. Freeze-branding had an advantage over using Petersen discs, or other external tags; there was less damage to the fish when recaptured in nets and no increased capture rate due to tags becoming caught in nets (Andersen \& Bagge 1963, International Council for the Exploration of the Sea 1965).

In total, the estuarine stations were fished on $>270$ occasions between January 1976 and July 1982, with in excess of 1200 trawl tows being made. In addition, recaptures were made by the research launches on other occasions while fishing for different species. Most of the fishing activity occurred between January 1976 and January 1979 (Table S1, available in the supplement at www.int-res.com/articles/suppl/m430 p183_supp.pdf). In general, the main stations were sampled at least monthly. Above T 20, sampling was undertaken as frequently as possible to provide information on flounder movements throughout the year, being restricted by water depth and river flow conditions (Table S1 in the supplement). Preliminary surveys showed that most flounder were found where there were extensive intertidal flats. Fishing concentrated on these areas, except where this was not possible because of moorings. Records of numbers of fish caught refer to flounder of $130 \mathrm{~mm}$ and upwards. Most fish were marked with an individual code, although 227 fish were marked with a brand that indicated only the date and place of capture. Within the estuary, Plymouth Sound and the approaches, 7401 flounder were marked (Table 1). A further 1667 fish were branded, using batch marks, at sea on the spawning grounds between 2 March and 2 April 1976 (Table 2). These fish were released within the shaded area shown in Fig. 1 b.

Reward notices and photographs of branded fish were circulated to fishers. Recaptured flounder were re-measured and released, unless caught by other fishers. Most estuary recaptures were made by 2 research launches, while most sea recaptures were by commercial trawlers. Outside the estuary, otter trawling was carried out within Plymouth Sound, at Stns P4, P4A and P5 (Fig. 1b) and offshore at a number of stations, including grounds to the west of Plymouth towards Fowey and in Bigbury Bay to the east (Fig. 1b). Sex ratios, return rates from marking at different stations and other sites were compared using a Fisher's exact test programme (Microsoft Corporation 2010), used with permission from Microsoft.

To study long-distance homing, 200 fish were marked with Petersen discs. In the Tamar, 60 flounder from Stn T20 and 10 from T27 and T28 were released in the River Frome near East Stoke on 19 December 1977 (Fig. 2a). A further 25 flounder from T19 and T20 were released into the Frome, and 105 flounder from T9 were released into Poole Harbour, at Baiter, on 26 January 1978 (Fig. 2a). The fish, 174 to $384 \mathrm{~mm}$ in length, were caught between 3 November and 16 December 
Table 1. Platichthys flesus. Totals of fish captured, marked and recaptured at each station. RS: total recaptures at station; TRMS: total recaptures anywhere of fish marked at this station; RSMS: total recaptures at station of fish marked at station; ROEPS: total recaptures of fish marked at station at other estuary and Plymouth Sound stations; RSS: recaptures at sea of fish marked at station; p represents the probability that the proportion of fish recaptured at other estuary and sound stations, of total estuary and sound recaptures from the marking station, is similar to that found in the overall totals

\begin{tabular}{|c|c|c|c|c|c|c|c|c|}
\hline Stn & No. caught & No. marked & RS & TRMS & RSMS & ROEPS & RSS & $\mathrm{p}$ \\
\hline P4 & 13 & 5 & 0 & 1 & 1 & 0 & 0 & \\
\hline P5 & 9 & 8 & 0 & 0 & 0 & 0 & 0 & \\
\hline $\mathrm{T} 2$ & 1463 & 926 & 152 & 172 & 147 & 8 & 17 & 0.099 \\
\hline T8 & 56 & 55 & 1 & 0 & 0 & 0 & 0 & \\
\hline T9 & 5803 & 2680 & 679 & 635 & 601 & 20 & 14 & $<0.001$ \\
\hline $\mathrm{T} 10$ & 956 & 357 & 36 & 33 & 26 & 4 & 3 & 0.518 \\
\hline T11 & 76 & 71 & 3 & 4 & 0 & 4 & 0 & $<0.001$ \\
\hline T12 & 3752 & 1634 & 306 & 302 & 269 & 25 & 8 & 0.739 \\
\hline T16 & 3 & 0 & 0 & 0 & 0 & 0 & 0 & \\
\hline T18 & 9 & 0 & 0 & 0 & 0 & 0 & 0 & \\
\hline T19 & 256 & 128 & 2 & 2 & 2 & 0 & 0 & \\
\hline T20 & 1840 & 543 & 40 & 38 & 28 & 10 & 0 & 0.002 \\
\hline $\mathrm{T} 22$ & 167 & 113 & 5 & 8 & 2 & 6 & 0 & $<0.001$ \\
\hline T26 & 11 & 3 & 0 & 1 & 0 & 1 & 0 & \\
\hline T27 & 152 & 130 & 5 & 19 & 1 & 18 & 0 & $<0.001$ \\
\hline T29 & 1218 & 748 & 99 & 93 & 71 & 22 & 0 & $<0.001$ \\
\hline Totals & 15784 & 7401 & 1314 & 1308 & 1148 & 118 & 42 & \\
\hline
\end{tabular}

Table 2. Platichthys flesus. Recaptures of flounder branded on the Rame-Fowey spawning grounds between 2 March and 2 April 1976 and recaptured elsewhere. M: male; F: female

\begin{tabular}{|c|c|c|c|c|c|c|c|c|c|}
\hline \multirow{3}{*}{$\begin{array}{l}\text { Capture } \\
\text { and branding } \\
\text { date }\end{array}$} & \multirow{2}{*}{\multicolumn{2}{|c|}{ No. marked }} & \multicolumn{6}{|c|}{-No. recaptured- } & \multirow{3}{*}{$\begin{array}{l}\text { Out-of-area recaptures } \\
\text { (date, sex, position) }\end{array}$} \\
\hline & & & \multicolumn{2}{|c|}{ Tamar } & \multicolumn{2}{|c|}{ Sea 1976} & \multicolumn{2}{|c|}{ Sea 1977} & \\
\hline & M & $\mathrm{F}$ & M & $\mathrm{F}$ & M & $\mathrm{F}$ & M & $\mathrm{F}$ & \\
\hline 2 Mar 1976 & 91 & 54 & 0 & 1 & 0 & 1 & 0 & 0 & $24 \mathrm{Mar} 1976, \mathrm{M}, 50^{\circ} 30.0^{\prime} \mathrm{N}, 2^{\circ} 57.0^{\prime} \mathrm{W}$ \\
\hline 4 Mar 1976 & 165 & 73 & 1 & 3 & 4 & 0 & 6 & 0 & 30 Mar $1976, \mathrm{M}, 50^{\circ} 16.8^{\prime} \mathrm{N}, 3^{\circ} 57.8^{\prime} \mathrm{W}$ \\
\hline 5 Mar 1976 & 122 & 72 & 0 & 2 & 5 & 0 & 0 & 0 & \\
\hline 8 Mar 1976 & 217 & 97 & 0 & 1 & 7 & 2 & 0 & 0 & 30 Mar $1976, \mathrm{M}, 50^{\circ} 16.8^{\prime} \mathrm{N}, 3^{\circ} 57.8^{\prime} \mathrm{W}$ \\
\hline 16 Mar 1976 & 81 & 34 & 2 & 0 & 1 & 1 & 0 & 0 & \\
\hline 17 Mar 1976 & 109 & 58 & 2 & 2 & 3 & 1 & 0 & 0 & $\begin{array}{l}22 \mathrm{Mar} 1976, \mathrm{M}, 50^{\circ} 37.7^{\prime} \mathrm{N}, 3^{\circ} 26.5^{\prime} \mathrm{W} \\
30 \mathrm{Mar} 1976, \mathrm{M}, 50^{\circ} 16.8^{\prime} \mathrm{N}, 3^{\circ} 57.8^{\prime} \mathrm{W}\end{array}$ \\
\hline 18 Mar 1976 & 105 & 52 & 2 & 1 & 2 & 0 & 1 & 0 & \\
\hline 19 Mar 1976 & 125 & 59 & 0 & 2 & 3 & 0 & 0 & 0 & \\
\hline 1 Apr 1976 & 45 & 21 & 0 & 0 & 1 & 0 & 0 & 0 & \\
\hline 2 Apr 1976 & 61 & 26 & 0 & 1 & 0 & 0 & 0 & 0 & \\
\hline Totals & 1121 & 546 & 7 & 13 & 26 & 5 & 7 & 0 & \\
\hline
\end{tabular}

1977 for the first release and on 23 and 24 January 1978 for the second. Fish were kept in tanks at the Marine Biological Association until they were transferred to aerated tubs of seawater or freshwater (as appropriate) for transfer by road.

\section{RESULTS}

\section{Spawning migrations}

Male flounder Platichthys flesus from which milt could be expressed were captured in the estuary as early as 23 November. In 1976, the first spent females were captured at Stn T2 on 27 February and in 1977 , on 19 January. In contrast to the males, the female fish underwent final maturation at sea, and ripe females were caught, almost exclusively, in the Rame-Fowey area (Fig. 1). No ripe eggs could be expressed from maturing females caught within the estuary or seen in dissected gonads from estuary-caught fish, other than a few in recently spent females.

From March until the beginning of April 1976, 1121 male and 546 female flounders were caught and marked on the Rame-Fowey spawning grounds (Table 2). Males were more numerous than the females by $\sim 2: 1$ $(p<0.001)$. The proportion of male flounder caught on the spawning grounds in that period was significantly 


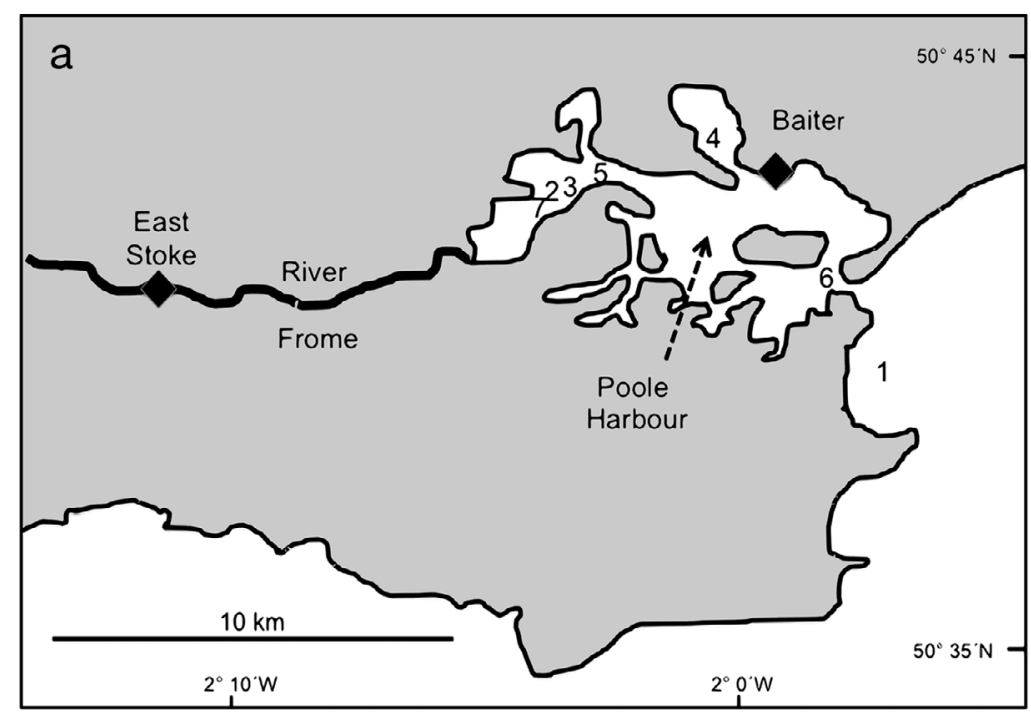

Fig. 2. Platichthys flesus. Release and recapture positions of flounder released in the River Frome and in Poole Harbour: (a) release positions $(\checkmark)$; recaptures, within the vicinity of Poole Harbour, of fish released in the Frome, are shown by numbers, in order of recapture date-1: 29 Dec 1977; 2: 4 Jan 1978 (2 fish); 3: 5 Jan 1978; 4: 19 Jan 1978; 5: 8 Feb 1978; 6: 4 Apr 1978; 7: 26 Apr 1978; (b) positions and dates of recapture of fish released in the Frome $(\Delta)$ and Poole Harbour (*) and caught at sea or in other estuaries. Maps reproduced from ordnance survey data by permission of the Ordnance Survey (Crown copyright 2010)

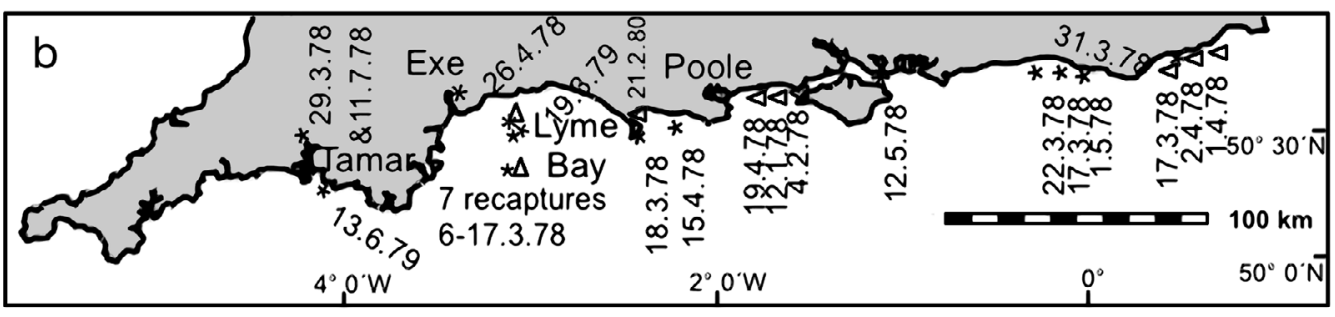

higher $(\mathrm{p}<0.003)$ than that of males captured in the lower and mid-estuary in November 1976 (313 males, 210 females from Stns T2, T9 and T12). Recaptures of sea-marked flounders on the spawning grounds comprised 26 males and 5 females in 1976, and 7 males in 1977 (Table 2). Twenty-one of the sea-marked fish were recaptured within the Tamar estuary, including 11 females, 4 at T2, 14 at T9, 2 at T12 and 1 at T29. The numbers of sea-marked flounders recovered at the different stations were not significantly different ( $p=0.16$ ) from those expected, after considering the total number of fish captured at each station postmarking (data from Table S1 in the supplement). Significantly more sea-marked females (13 female, 7 male, 1 not sexed) were recaptured in the estuary than would have been expected by the sex ratio on marking $(\mathrm{p}<0.004)$.

Towards the end of the spawning season, between 15 March and 12 April 1976, 45 male and 249 female flounder were caught at T2 and T9, a significantly greater proportion of females $(p<0.001)$ than that caught in the pre-spawning period or on the spawning grounds. Of the flounder caught in the estuary between 15 March and 12 April 1976, 22 were females, including 2 previously marked on the spawning grounds, only 2 marked males were re-captured. Post-spawning, between May and July 1976, the sex ratio of the flounders caught at T2 and T9 had returned to the expected 1:1 ratio, 123 males and 124 females being caught. The numbers of flounder of each sex caught at T 29 over the same period were similar, 38 males and 44 females.

Only 5 marked fish, $12 \%$ of sea-marked recaptures, were caught at sites other than the spawning grounds or in the Tamar estuary, all of these were males and recaptured east of Plymouth. Three were from Bigbury Bay, 1 from the Exe estuary and 1 from $70 \mathrm{~km}$ west in Lyme Bay (Table 2, Fig. 2b). Some flounder, captured at sea and branded prior to the completion of spawning in 1980, were released at P3. Two, both males, were caught in Bigbury Bay and released on 29 February 1980. One was recaptured 10 d later on the spawning grounds west of Plymouth, and the second was recaptured on 2 April 1980, also to the west on the spawning grounds. These could have been fish from small rivers east of Plymouth, caught while moving west, or Tamar fish that did not migrate with the majority of the population. Another ripe male was captured on the spawning grounds, released at P3 on 6 March 1980 and recaptured on the spawning grounds again on 9 April 1980. Similarly, a ripe female, caught west of Rame on the spawning grounds was released on 18 March 1980 and recaptured at sea in approximately the original position 13 d later.

The first flounders captured in the year at sea, west of Plymouth, were all males. In 1976, this was on 14 January and, in 1977, on 19 January. Female fish were 
Table 3. Platichthys flesus. Recapture positions of flounder branded in the Tamar estuary and recaptured east of Plymouth

\begin{tabular}{|lcccc|}
\hline $\begin{array}{l}\text { Recapture } \\
\text { date }\end{array}$ & $\begin{array}{c}\text { Marking } \\
\text { station }\end{array}$ & $\begin{array}{c}\text { Marking } \\
\text { date }\end{array}$ & Sex & $\begin{array}{c}\text { Recapture } \\
\text { location }\end{array}$ \\
\hline 24 Mar 1976 & T9 & 3 Feb 1976 & $\mathrm{F}^{\mathrm{a}}$ & $50^{\circ} 24.0^{\prime} \mathrm{N}, 3^{\circ} 19.0^{\prime} \mathrm{W}$ \\
6 Apr 1976 & T9 & 15 Mar 1976 & $\mathrm{M}$ & $50^{\circ} 16.8^{\prime} \mathrm{N}, 3^{\circ} 57.8^{\prime} \mathrm{W}$ \\
12 Feb 1977 & T10 & 19 Jan 1977 & $\mathrm{M}$ & $50^{\circ} 27.6^{\prime} \mathrm{N}, 3^{\circ} 15.6^{\prime} \mathrm{W}$ \\
3 Mar 1977 & T10 & 19 Jan 1977 & $\mathrm{M}$ & $50^{\circ} 27.6^{\prime} \mathrm{N}, 3^{\circ} 15.6^{\prime} \mathrm{W}$ \\
16 Mar 1977 & T9 & 17 Jan 1977 & $\mathrm{M}$ & $50^{\circ} 240^{\prime} \mathrm{N}, 3^{\circ} 18.6^{\prime} \mathrm{W}$ \\
${ }^{\mathrm{S}}$ Spent & & & & \\
\hline
\end{tabular}

first captured on 10 February in 1976 and on 31 January in 1977. Most of the 42 recaptures at sea, of Tamarmarked flounder, were from water depths of $\sim 35$ to $\sim 55 \mathrm{~m}$ between Rame Head and Fowey (Fig. 1b), i.e. from distances of up to $35 \mathrm{~km}$ west of Plymouth Sound. No recaptures were made further west, and only 5 recaptures $(12 \%)$ were from east of Plymouth (Table 3). There was no indication of a time or spatial separation in the recaptures of fish from different estuarine stations on the spawning grounds (Fig. 1b). Comparing sea recaptures after the 1976 spawning season, since only flounder from T2 and T9 had been marked prior to this, 23 recaptures came from 4695 fish marked in the lower middle estuary (T2 to T12) and no recaptures were made of the 1666 flounder marked between T19 and T29 (data from Table S1 in the supplement). Although many of the lower to mid-estuary marked fish were marked in winter and would have included fish displaced from the upper estuary, this difference in recapture rates is significant $(p=0.0014)$.

\section{Site fidelity of flounder in the lower and middle estuary}

Details of the number of fish marked and the number of marked fish recaptured at each station are given in Table 1, together with the number of recaptures from fish marked at that station. The latter are sub-divided into the numbers recaptured at the marking station, the number caught elsewhere in the Tamar estuary and Plymouth Sound, and the number caught at sea. Details of fish marked and recaptured at each station on each day are given in Table S1 in the supplement.

Within the estuary or in Plymouth Sound, 1266 recaptures of individuals marked within the estuary were made (Table 1); $90.7 \%$ of these (1148) were from the original marking site. In the lower and middle estuary, a significantly higher recapture rate $(97 \%)$ was obtained at Stn T9 (Table 1). Site fidelity at Stns T2 $(96 \%)$, T10 (87\%) and T12 (92\%) were not significantly different from the overall mean (Table 1).
Stn T11 was the exception, in that all 4 of the recaptures of fish marked at the station were from other sites.

In the middle estuary, movement of fish between adjacent trawling stations was very limited (Table 4). At T9, only 3 of 621 estuarine- and sound-marked recaptures were marked at T10. Similarly, only 2 of 30 estuarine-marked recaptures at T10 came from T9. If populations at the T9 and T10 sites freely assorted, significantly more of the flounders captured at T10 should have been marked at T9. For example, on 4 March 1977, 31 flounder were caught at T9; all 4 that were recaptures had been marked at T9. On the same day, 122 flounder were captured at T10, with 2 recaptures, both marked at T10. The numbers of T9 recaptures at the 2 sites were significantly different $(\mathrm{p}=$ $0.0014)$ from those expected by random distribution. Similarly, on 15 April 1977, 10 recaptures of T9 fish were made at T9, out of a catch of 45 fish, whereas, at T10, only a single T9 recapture was obtained from a catch of 48 fish; the numbers of T9 recaptures at the 2 sites were again significantly different $(p=0.003)$.

Some fishers stop-netted (at high tide) inlets that lead off $\mathrm{T} 9$, and several flounder marked at $\mathrm{T} 9$ were recovered at low water. No flounder were caught at these sites the following day and no marked fish were among the flounders the same fishers caught using the same nets in the Tavy, $2 \mathrm{~km} \mathrm{NE}$ of T9.

The T8 tow lies off the opposite bank to T9 (Fig. 1c). Stn T8 was fished on 14 July 1977, when 56 flounder were caught, including 1 marked at T9. On the same day, 41 fish were caught at T9, of which 7 were previously marked at T9. The ratio of T9 recaptures at the 2 sites is significantly different from that expected by free movement between the sites $(p<0.01)$. Only 55 flounder were marked at T8. The number of fish marked on 14 July 1977 and subsequently at T9 was 374 , of which 90 recaptures were later made at T9, with no T8 fish being recaptured. Had the flounder moved freely between the 2 sites then at least $13 \mathrm{~T} 8$ flounder should have been recaptured at T9. This difference in recaptures was again significant $(p<0.001)$.

Multiple recaptures of individuals showed they returned to the same estuarine site post-spawning. For example, a female of $328 \mathrm{~mm}$ total length, marked at T9 on 3 February 1976, was recaptured there again, pre-spawning on 13 February and post-spawning on 29 March and 8 October 1976. It was recaptured prespawning in 1977 on 18 March and later that year on 12 December. The last recapture of this individual was on 22 March 1978, post-spawning, with a length of $348 \mathrm{~mm}$. All these recaptures were at T9.

At sea, 42 recaptures of estuary-marked fish were made, associated with annual spawning migration (Fig. 1b, Table 1). Only $61(5.5 \%)$ of the estuary and sound recaptures, from flounder marked at T2 to T12, 
Table 4 (this and next page). Platichthys flesus. Dates and positions of fish marked at one station and recaptured elsewhere in the Tamar estuary and Plymouth Sound, with notes on probable explanations for this. SM: spawning migration, PSM: post-spawning migration

\begin{tabular}{|c|c|c|c|c|c|}
\hline Marking date & $\begin{array}{c}\text { Marking } \\
\text { station }\end{array}$ & $\begin{array}{l}\text { Recapture } \\
\text { station }\end{array}$ & $\begin{array}{l}\text { Recapture } \\
\text { date }\end{array}$ & $\begin{array}{c}\text { Subsequent } \\
\text { recaptures }\end{array}$ & Notes \\
\hline 13 Feb 1976 & $\mathrm{~T} 2$ & $\mathrm{P} 4 \mathrm{~A}$ & 17 Jun 1976 & & \\
\hline 13 Feb 1976 & $\mathrm{~T} 2$ & $\mathrm{P} 4 \mathrm{~A}$ & 31 Oct 1978 & & \\
\hline 27 Feb $1976^{a}$ & $\mathrm{~T} 2$ & T9 & 30 Mar 1976 & & PSM \\
\hline 27 Feb $1976^{a}$ & $\mathrm{~T} 2$ & T9 & 25 Oct 1977 & & PSM \\
\hline $29 \operatorname{Mar} 1976^{a}$ & T2 & T9 & 26 May 1976 & & PSM \\
\hline $30 \operatorname{Mar} 1976^{a}$ & $\mathrm{~T} 2$ & T11 & 6 Jan 1977 & & PSM \\
\hline $30 \operatorname{Mar} 1976^{a}$ & $\mathrm{~T} 2$ & T9 & 27 Feb 1976 & & PSM \\
\hline 12 Apr 1976 & $\mathrm{T} 2$ & T9 & 25 May 1976 & & PSM \\
\hline 29 Jun 1977 & $\mathrm{~T} 2$ & T9 & 28 Sep 1977 & & \\
\hline 13 Feb 1976 & T9 & T12 & 23 Nov 1977 & T9, 9 Jan 1978 & Spate \\
\hline 30 Mar $1976^{a}$ & T9 & T13 & 28 Mar 1977 & & PSM \\
\hline 26 May 1976 & T9 & T19 & 7 Nov 1976 & & \\
\hline 5 Nov 1976 & T9 & $\mathrm{T} 8$ & 15 Jul 1977 & & \\
\hline 19 Jan 1977 & T9 & T10 & 18 Feb 1977 & T10, 15 Apr 1977 & \\
\hline 20 Jan 1977 & T9 & P4A & 3 Sep 1979 & & \\
\hline 21 Jan 1977 & T9 & $\mathrm{T} 2$ & 19 Jul 1982 & & \\
\hline 18 Feb 1977 & T9 & $\mathrm{T} 12$ & 10 Jan 1978 & & \\
\hline 4 Mar 1977 & T9 & $\mathrm{P} 4 \mathrm{~A}^{\mathrm{b}}$ & 7 Mar 1980 & & SM \\
\hline 18 Mar 1977 & T9 & $\mathrm{T} 10$ & 18 May 1977 & & \\
\hline 18 Mar 1977 & T9 & $\mathrm{T} 2$ & 12 May 1980 & & \\
\hline 18 Apr 1977 & T9 & $\mathrm{T} 12$ & 13 Jun 1977 & & \\
\hline 4 Apr 1977 & T9 & $\mathrm{T} 10$ & 15 Jun 1977 & & \\
\hline 4 Apr 1977 & T9 & Т29 & 9 Aug 1977 & & Spate \\
\hline 18 Apr 1977 & T9 & $\mathrm{T} 12$ & 13 Jun 1977 & & \\
\hline 18 Apr 1977 & T9 & $\mathrm{T} 2$ & 24 Oct 1977 & & \\
\hline 18 Apr 1977 & T9 & $\mathrm{T} 12$ & 10 Jan 1978 & & \\
\hline 12 Oct 1977 & T9 & $\mathrm{T} 20$ & 3 Nov 1977 & & \\
\hline 11 Nov 1977 & T9 & T13 & 12 Jul 1979 & & \\
\hline 11 Nov 1977 & T9 & $\mathrm{P} 4 \mathrm{~A}$ & 26 Jun 1978 & & \\
\hline 19 Jan 1977 & $\mathrm{~T} 10$ & $\mathrm{~T} 11$ & 31 Mar 1977 & & \\
\hline 4 Mar 1977 & $\mathrm{~T} 10$ & Т9 & 24 Jan 1978 & & \\
\hline 17 Mar 1977 & $\mathrm{~T} 10$ & T9 & 12 Dec 1977 & & \\
\hline 18 May 1977 & $\mathrm{~T} 10$ & T29 & 9 Aug 1977 & & \\
\hline 6 Jan 1977 & T11 & $\mathrm{T} 10$ & 18 May 1977 & & \\
\hline 6 Jan 1977 & T11 & T29 & 24 Jun 1977 & T29, 8 Aug 1977 & Spate \\
\hline 6 Jan 1977 & T11 & T9 & 9 Jan 1978 & & \\
\hline 13 Apr 1976 & T12 & T9 & 5 Nov 1976 & & \\
\hline 9 Jun 1976 & $\mathrm{~T} 12$ & $\mathrm{~T} 2$ & 12 May 1980 & & \\
\hline 9 Jun 1976 & $\mathrm{~T} 12$ & $\mathrm{P} 4 \mathrm{~A}$ & 5 May 1978 & & \\
\hline 9 Jun 1976 & $\mathrm{~T} 12$ & T9 & 24 Nov 1977 & & \\
\hline 26 Jul 1976 & $\mathrm{~T} 12$ & T20 & 1 Dec 1976 & & \\
\hline 26 Jul 1976 & $\mathrm{~T} 12$ & T9 & 7 Dec 1976 & & SM? \\
\hline 26 Jul 1976 & $\mathrm{~T} 12$ & T9 & 12 Dec 1978 & & \\
\hline 26 Jul 1976 & $\mathrm{~T} 12$ & T9 & 25 Nov 1977 & & \\
\hline 7 Sep 1976 & $\mathrm{~T} 12$ & $\mathrm{~T} 2$ & 17 Mar 1977 & & SM? \\
\hline 7 Sep 1976 & $\mathrm{~T} 12$ & T9 & 4 Apr 1977 & & \\
\hline 8 Nov 1976 & $\mathrm{~T} 12$ & $\mathrm{~T} 10$ & 19 Jan 1977 & & Spate \\
\hline 21 Dec 1976 & $\mathrm{~T} 12$ & Т20 & 19 Oct 1977 & & Spate \\
\hline 5 Jan 1977 & $\mathrm{~T} 12$ & T20 & 6 Jan 1977 & & \\
\hline 5 Jan 1977 & $\mathrm{~T} 12$ & T22 & 19 Oct 1977 & & \\
\hline 5 Jan 1977 & $\mathrm{~T} 12$ & T9 & 21 Apr 1982 & & PSM \\
\hline 5 Jan 1977 & $\mathrm{~T} 12$ & $\mathrm{~T} 20$ & 28 Jul 1977 & & \\
\hline 3 Mar 1977 & $\mathrm{~T} 12$ & T29 & 20 Oct $1977^{\mathrm{e}}$ & & Spate \\
\hline 17 Mar 1977 & $\mathrm{~T} 12$ & $\mathrm{~T} 10$ & 15 Jun 1977 & & \\
\hline 17 Mar 1977 & $\mathrm{~T} 12$ & T9 & 28 Sep 1977 & & \\
\hline 28 Sep 1977 & $\mathrm{~T} 12$ & T9 & 24 Nov 1977 & & \\
\hline 28 Sep 1977 & $\mathrm{~T} 12$ & T20 & 16 Mar 1978 & T20, 6 Apr 1978 & \\
\hline 23 Nov 1977 & $\mathrm{~T} 12$ & T9 & 12 Dec 1977 & & \\
\hline 23 Nov 1977 & $\mathrm{~T} 12$ & T9 & 26 Jan 1979 & & \\
\hline 24 Nov 1977 & T12 & T9 & 12 Dec 1978 & & \\
\hline
\end{tabular}


Table 4 (continued)

\begin{tabular}{|c|c|c|c|c|c|}
\hline Marking date & $\begin{array}{l}\text { Marking } \\
\text { station }\end{array}$ & $\begin{array}{l}\text { Recapture } \\
\text { station }\end{array}$ & $\begin{array}{l}\text { Recapture } \\
\text { date }\end{array}$ & $\begin{array}{l}\text { Subsequent } \\
\text { recaptures }\end{array}$ & Notes \\
\hline 1 Dec 1976 & $\mathrm{~T} 20$ & Т29 & 25 Jul 1977 & Т29, 22 Sep 1977 & Spate \\
\hline 1 Dec 1976 & $\mathrm{~T} 20$ & $\mathrm{~T} 27$ & 22 Aug 1977 & & Spate \\
\hline 1 Dec 1976 & T20 & T11 & 6 Jan 1977 & & SM? \\
\hline 1 Dec 1976 & $\mathrm{~T} 20$ & P5 & 7 Apr 1977 & & SM? \\
\hline 13 Jan 1977 & $\mathrm{~T} 20$ & $\mathrm{~T} 10$ & 19 Jan 1977 & & Spate \\
\hline 11 Feb 1977 & $\mathrm{~T} 20$ & T9 & 4 Apr 1977 & & \\
\hline 11 Feb 1977 & $\mathrm{~T} 20$ & $\mathrm{~T} 10$ & 30 Jun 1977 & & \\
\hline 11 Feb 1977 & $\mathrm{~T} 20$ & T29 & 22 Aug 1977 & & Spate \\
\hline 22 Apr 1977 & $\mathrm{~T} 20$ & $\mathrm{~T} 22$ & 18 Nov 1977 & & Spate \\
\hline 9 May 1977 & $\mathrm{~T} 22$ & $\mathrm{~T} 20$ & 16 Mar 1978 & & Spate \\
\hline 9 May 1977 & $\mathrm{~T} 22$ & $\mathrm{~T} 29$ & 22 Aug 1977 & & \\
\hline 22 Aug 1977 & $\mathrm{~T} 22$ & $\mathrm{~T} 12$ & 28 Sep 1977 & & \\
\hline 24 Aug 1977 & T22 & $\mathrm{T} 12$ & 9 Dec 1977 & & Spate \\
\hline 22 Sep 1977 & $\mathrm{~T} 22$ & T9 & 12 Oct 1977 & & Spate \\
\hline 22 Sep 1977 & $\mathrm{~T} 22$ & T9 & 19 Apr 1978 & & \\
\hline 7 Jul 1977 & T26 & T29 & 22 Aug 1977 & & \\
\hline 8 Jul 1977 & $\mathrm{~T} 27$ & T29 & 22 Aug 1977 & T9, 12 Dec 1977 & $\begin{array}{l}\text { Spate on } \\
12 \text { Dec } 1977\end{array}$ \\
\hline 8 Jul 1977 & Т27 & $\mathrm{T} 29$ & $25 \mathrm{Jul} 1977^{\mathrm{e}}$ & & \\
\hline 8 Jul 1977 & T27 & $\mathrm{T} 29$ & 21 Sep $1977^{f}$ & & \\
\hline 8 Jul 1977 & T27 & $\mathrm{T} 29$ & 20 Oct 1977 & & \\
\hline 8 Aug 1977 & T27 & $\mathrm{T} 29$ & 22 Aug 1977 & & \\
\hline 8 Aug 1977 & $\mathrm{~T} 27$ & T29 & 21 Sep $1977^{e}$ & & \\
\hline 8 Aug 1977 & $\mathrm{~T} 27$ & $\mathrm{~T} 29$ & 23 Aug $1977^{9}$ & & \\
\hline 8 Aug 1977 & $\mathrm{~T} 27$ & $\mathrm{~T} 29$ & 23 Aug 1977 & T29, 26 Oct 1977 & \\
\hline 18 May 1976 & $\mathrm{~T} 29$ & T9 & 5 Nov 1976 & & Spate \\
\hline 18 May 1976 & Т29 & T9 & 7 Dec 1976 & & Spate \\
\hline 19 May 1976 & T29 & $\mathrm{T} 21$ & 22 Jul 1976 & & $\begin{array}{l}\text { High temperatures, } \\
\text { low oxygen at T29 }\end{array}$ \\
\hline 19 May 1976 & Т29 & T9 & 7 Dec 1976 & & Spate \\
\hline 7 Jul 1977 & $\mathrm{~T} 29$ & $\mathrm{~T} 20^{\mathrm{c}}$ & 16 Dec 1977 & & Spate \\
\hline 8 Jul 1977 & $\mathrm{~T} 29$ & $\mathrm{~T}^{\mathrm{d}}$ & 12 Dec 1977 & & Spate \\
\hline 25 Jul 1977 & $\mathrm{~T} 29$ & $\mathrm{~T} 20$ & 28 Jul 1977 & & \\
\hline 25 Jul 1977 & T29 & T27 & 9 Aug 1977 & & \\
\hline 8 Aug 1977 & T29 & $\mathrm{T} 27$ & 9 Aug 1977 & & \\
\hline 9 Aug 1977 & $\mathrm{~T} 29$ & T27 & 26 Jul 1978 & & \\
\hline 22 Aug 1977 & $\mathrm{~T} 29$ & $\mathrm{~T} 22$ & 24 Aug $1977^{\mathrm{e}}$ & & \\
\hline 22 Aug 1977 & T29 & $\mathrm{T} 22$ & 19 Oct 1977 & & \\
\hline 22 Aug 1977 & Т29 & $\mathrm{T} 20$ & 4 Jan 1978 & & Spate \\
\hline 22 Aug 1977 & $\mathrm{~T} 29$ & T9 & 9 Jan 1978 & & Spate \\
\hline 22 Aug 1977 & $\mathrm{~T} 29$ & T20 & 16 Mar 1978 & & Spate \\
\hline 22 Aug 1977 & T29 & T20 & 22 Jan 1979 & & \\
\hline 22 Aug 1977 & T29 & T27 & 26 Jul 2008 & & \\
\hline 23 Aug 1977 & T29 & T9 & 20 Jun 1978 & & \\
\hline 23 Aug 1977 & T29 & $\mathrm{P} 4 \mathrm{~A}$ & 28 Apr 1980 & & PSM \\
\hline 21 Sep 1977 & T29 & T20 & 16 Dec 1977 & & Spate \\
\hline 22 Sep 1977 & T29 & $\mathrm{T} 20$ & 16 Dec 1977 & & Spate \\
\hline
\end{tabular}

were made at positions, in the estuary or sound, other than the original capture sites (Table 4). Of these 61, 8 were caught at sites adjacent to the marking sites, a further 11 recaptures could be explained by fish caught during migrations to, or from, the spawning grounds and 8 were probably fish displaced during high river flows, 'spates' (Table 4). The latter was demonstrated by comparing the catch rate at $\mathrm{T} 12$, where the main channel was fished, with the highest river flow since the previous catch (Fig. 3). Catch rates tended to peak after periods when the river flow exceeded $30 \mathrm{~m}^{3} \mathrm{~s}^{-1}$.

Five recaptures of estuary-marked flounder (2 from T2, 2 from T9 and 1 from T12) were from Plymouth Sound during the summer. Only 5 flounder were marked at P4, 4 were marked pre-spawning on 6 January 1977 and 1 of these fish was recaptured in the sound on 24 March 1977, after spawning. 


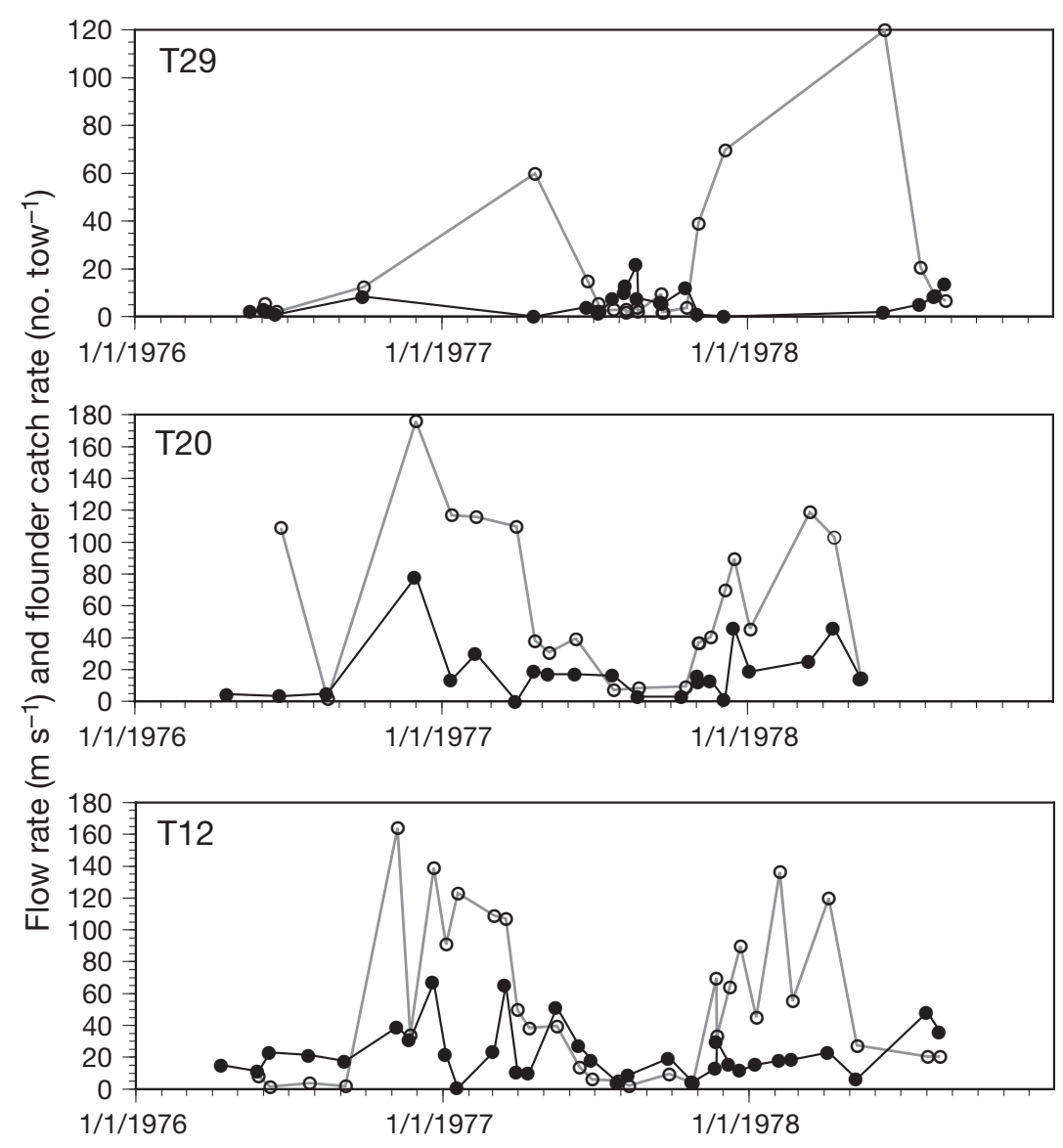

Fig. 3. Platichthys flesus. Variation of flounder catch with river flow: catch rates, at Stns T12, T20 and T29 (0); maximum river flow over weir, since the previous catch record at the station (O). Dates: 1 Jan 1976, 1977 and 1978

water column from below T22, was still fresh and T20 had a bottom salinity of only 5.5 PSU at high water. Only a single flounder was captured at T22, and none above this. On 1 December 1976, the river flow at Gunnislake Weir had increased to $139 \mathrm{~m}^{3} \mathrm{~s}^{-1}$. The estuary above T21 was devoid of flounder. Six days later, at T9, fish marked at T13 and at T29 were recovered.

Low river flows could have similar consequences. The year 1976 was exceptionally dry in July and August (Fig. 3), with mean daily flow rates of 1.18 and $0.76 \mathrm{~m}^{3} \mathrm{~s}^{-1}$, respectively. The recapture of a fish, marked at T29, in salmon nets at T21 on 22 July 1976 occurred at a time when numbers of salmon were dying in the upper reaches due to low river flows, high temperatures and low oxygen levels (S. Bray pers. comm.).

\section{Displacement and homing}

The homing ability of flounder within the estuary was tested by 18 releases (681 fish in total) to sites within the estuary or Plymouth Sound that were distinct from the capture sites (Table 5). Of these fish, 128 were recaptured, 114 from the marking site and only 2 from the release site. The numbers of dis-

\section{Site fidelity of flounder in the upper estuary}

The upper estuary sites (Stns T20, T22, T27 and T29) showed significantly lower recapture percentages of fish that were marked at the individual sites, $(74,25$, 5 and $76 \%$ respectively) than the 87 to $96 \%$ fidelity observed for the lower-middle estuary sites (Table 1), with 57 flounder being caught at sites in the estuary and sound other than their marking site. However, 21 of these were movements between T27 and T29, 3 could be explained by spawning or post-spawning migrations and 19 could be explained by marking or recapture at times when fish were displaced from the upper estuary during periods of high river flow.

At T29, flounder were absent, or present in low numbers, when river flows exceeded $\sim 30 \mathrm{~m}^{3} \mathrm{~s}^{-1}$ (Fig. 3a). Conversely, at T20, where the estuary widens to $\sim 100 \mathrm{~m}$, the catch rate increased (Fig. 3b). An example of this physical displacement of fish is shown by the recapture of a T29 marked fish at T9 on 5 November 1976, when the mean flow over the weir had been $>42 \mathrm{~m}^{3} \mathrm{~s}^{-1}$ for $4 \mathrm{~d}$. Ten d later, when the flow had dropped to $16 \mathrm{~m}^{3} \mathrm{~s}^{-1}$, the placed fish recaptured at the marking sites were not significantly different $(p=0.18)$ to the numbers recaptured from those released directly at the marking site, 124 fish from 898 released (Table 5).

The return of the fish to their original site was rapid. Nine fish displaced during 29 to 30 March 1976 from Stn T9 to Stn T2 were recaptured at T9 between 13 and 15 d later. A fish from T2, released at Stn P3 on 4 January 1980, was recaptured $7 \mathrm{~d}$ later at T2, and a further 4 fish from this release were recaptured at $\mathrm{T} 2$, by 16 February 1980, prior to spawning. Similarly, 2 T2 fish released 6 d later at T2 at P 3 on 23 January 1980 were recaptured, before spawning. A further 2 T2 fish released at P3 on 1 February 1980 were recaptured at T2, before spawning, 14 d later.

All the 14 displaced fish that were recaptured away from the original marking sites could be explained by spawning migrations, or by the displacement of fish from the upper reaches of the estuary by river spates. Flounder marked at the upper stations and displaced by the autumn/winter spates, returned to the marking stations, after spawning, the following year. 
Table 5. Platichthys flesus. Flounder marked and displaced within the Tamar estuary, together with those not displaced on the same dates, with sites of recapture. SG: Rame-Fowey spawning grounds, see Fig. 1 for other sites

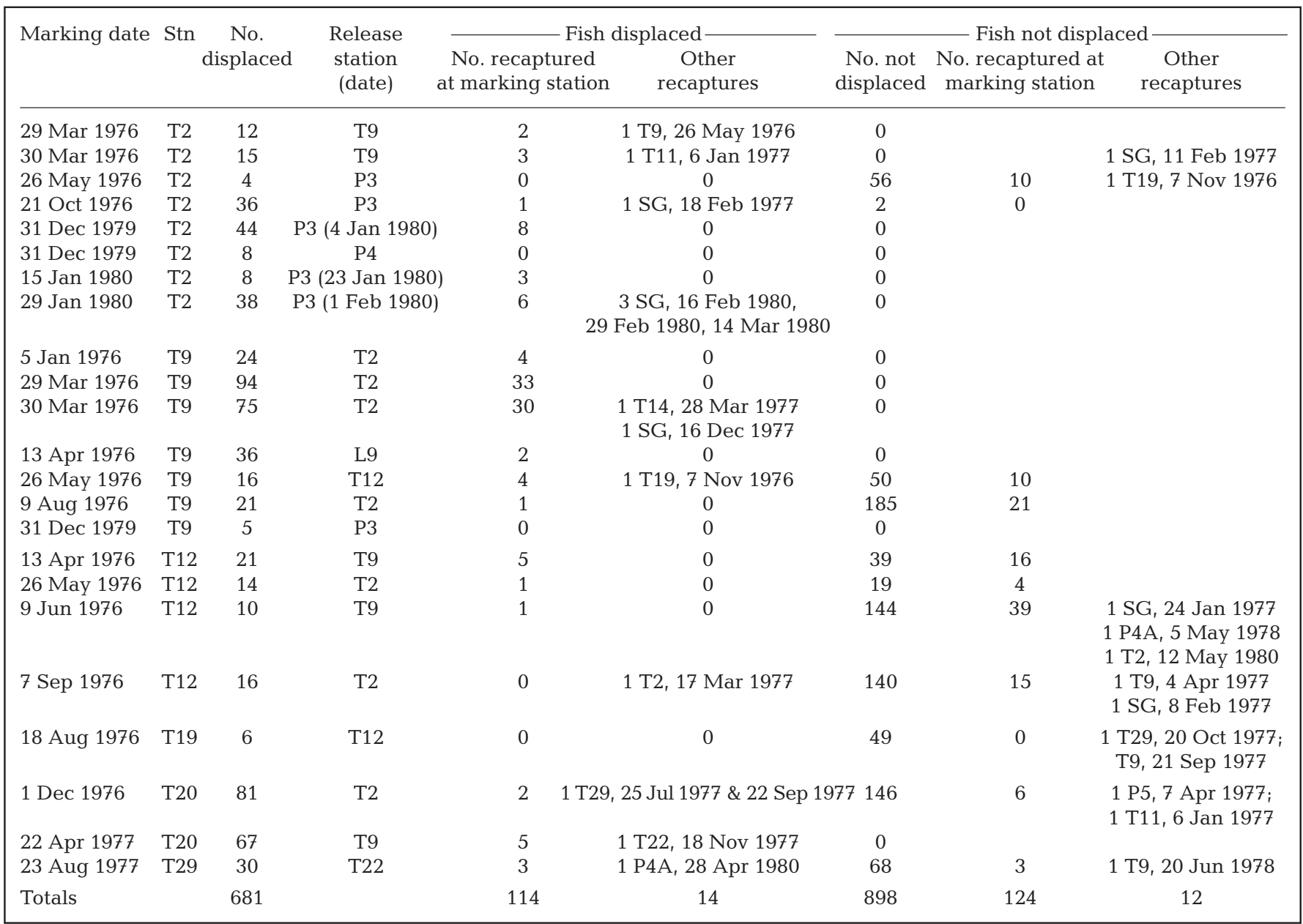

\section{Displacement of flounder to Poole Harbour and the River Frome}

A total of 200 Tamar flounder, tagged with Petersen discs, were released in the River Frome and Poole Harbour, $200 \mathrm{~km}$ east of Plymouth (Fig. 2). The positions and dates of recapture of all the migrating fish captured at sea are shown in Fig. 2b. In total, there were 26 recaptures of fish released in the Frome and 46 of those released in Poole Harbour, i.e. $35 \%$ of the number released.

The first recapture, of a fish released in the Frome on 19 December 1977, was made 10 d later, just south of Poole Harbour (Fig. 2a). Four Frome fish were caught in the inner part of Poole Harbour in early to mid-January 1978. Sixteen of the 200 released fish had been caught at sea by the end of March (Fig. 2b). In total, 27 fish were recaptured away from Poole Harbour, 16 of these to the west and 11 to the east. Three fish were recaptured in the Plymouth area, 2 were recaptured in the Tamar. The first was recaptured at Stn T12, on 29 March following release in the Frome, a total of $100 \mathrm{~d}$ in which the fish had travelled a minimum distance of $240 \mathrm{~km}$ by river and sea. No fish were recaptured west of Plymouth.

Of the fish released into Poole Harbour, 29 were recaptured within the harbour (results not shown), 13 prior to the end of April and 16 after 1 May 1978. The latter group was assumed to have returned to the harbour after spawning. Similarly, 7 of the flounder released in the Frome were recaptured within Poole Harbour after 1 May 1978.

\section{DISCUSSION}

Although these studies were undertaken between 1976 and 1980, there is no evidence of substantial changes in the Tamar flounder Platichthys flesus population over the last $100 \mathrm{yr}$. The earliest records of 
flounder sizes and catches were made by Holt (1897) from 1891 to 1894. A detailed study of flounder in the lower estuary was undertaken from 1937 to 1938 (Wilson 1939, Hartley 1940, 1947). Although it was not possible to study Hartley's fishing stations in the lower estuary, since wartime developments and moorings made the grounds unworkable (P. H. T. Hartley pers. comm.), the numbers and sizes of fish caught in all these studies were similar to those found in the 1970s, since Hartley gives details of the area swept by the tuck net used in the earlier studies (results not shown). McHugh et al. (2011) compared fishing records from Plymouth Sound and other inshore sites near Plymouth from 1913 to 1922 with those from 2008 to 2009. No significant differences were found between flatfish catches, including flounder, in the 2 periods. It is reasonable to assume that the results reported are applicable to the present-day flounder population.

\section{Spawning grounds and pre- and post-spawning migrations}

Although Platichthys flesus in the Tamar was described by Hartley (1940) as 'the estuarine fish par excellence' it is not wholly estuarine, and spawns at sea. All known flounder populations are sea-spawning; indeed few 'estuarine' fish species spawn in the Tamar (Dando 1984). The returns of Tamar flounder from offshore grounds (Fig. 1b, Table 1) showed that the main spawning grounds are between Rame Head and Fowey, 10 to $30 \mathrm{~km}$ west of Plymouth, over water depths of 35 to $55 \mathrm{~m}$. There was no indication that flounder from different areas of the Tamar segregated on the spawning grounds (Fig. 1b). However, no fish from the upper estuary were recaptured at sea, and there is a possibility that these flounder spawn elsewhere, although recaptures of 2 fish marked in the upper estuary and recaptured in Plymouth Sound in April show that they also spawn at sea, and the recapture at Stn T29 of 2 fish marked on the spawning grounds suggest that they do spawn in the same area as the fish from the lower estuary. Flounder spawning areas north of Dieppe and in the Helgoland Bight are also offshore (van der Land 1991, Cameron et al. 1992), where water depths are between 25 and $50 \mathrm{~m}$.

Peak densities on the Rame-Fowey spawning grounds usually occur in March, although earlier migration occurs with lower estuary temperatures (Sims et al. 2004). Similarly, Platichthys olivaceus migrate offshore when coastal water temperatures fall (Yasuda et al. 2010). Male flounder left the estuary earlier than females and tended to return later, as demonstrated by a significantly higher proportion of male fish captured at sea, as well as by an increase in the percentage of adult females captured in the estuary from mid-March to mid-April. The sex ratios of fish caught in the estuary returned to the expected 1:1 ratio later in the year.

The eastward movement along the coast of $12 \%$ of both the sea-marked and Tamar-marked founder may be an underestimate. Since reward notices were not circulated to all fishers further east, it is likely that substantially more branded fish moved east than was suggested by the recapture rate. This assumption is supported by the high percentage of recaptures $(41 \%)$ of flounder, tagged with the more visible Petersen discs, that moved east from Poole; 3 as far as $170 \mathrm{~km}$ (Fig. 2b). Two, of 4 flounder tagged by Hartley (1940) and recovered at sea, were recovered well to the east of Plymouth, one $\sim 360 \mathrm{~km}$ east.

The ability of the Tamar fish to locate their spawning grounds, or to find their way back to the estuary after spawning, is not as good as their ability to home within the estuary and Plymouth Sound. This inability of such a high percentage of flounder to return to their home estuary after spawning, if typical of other estuaries, would explain the finding of a high genetic uniformity of individuals throughout the range of the subspecies Platichthys flesus flesus in the Atlantic from the UK and North Sea to Spain (Galleguillos \& Ward 1982, Berrebi et al. 1983, 1985, Borsa et al. 1997). Recent studies using DNA markers support the suggestion of high gene flow in this region, although proposing a genetic discontinuity in gene flow north of the Bay of Biscay (Hemmer-Hansen et al. 2007a). Although local genetic selection and/or seasonal segregation of genotypes may occur (Marine Biological Association of the United Kingdom 1973, Hemmer-Hansen et al. 2007b, Larsen et al. 2007, 2008), the high degree of mixing between populations explains why geographic clines in allele frequencies are small over this range. Marked gene clines in the Baltic flounder are believed to be due to a mixture of 2 or more subspecies (Draganik et al. 2007, Florin \& Höglund 2008) and possibly 6 flounder stocks (International Baltic Seas Fisheries Commission 1998).

Seven flounder, all males, marked on the Rame-Fowey spawning grounds in 1976 were recaptured on these grounds the following year, suggesting some site fidelity to the spawning grounds. Since very few of the Tamarmarked fish were recaptured and re-released on the spawning grounds, it was not possible to estimate their fidelity to the spawning grounds. Plaice show a fidelity of at least $94 \%$ to Icelandic spawning grounds, within $30 \mathrm{~km}$ of the marking site, in the year after tagging, declining to $72 \%$ thereafter (Solmundsson et al. 2005). A similar fidelity to spawning grounds was found for North Sea plaice using data storage tags (Hunter et al. 2003).

Most Tamar flounder returned to the estuary and to their original marking location, as demonstrated by the multiple recaptures of individuals, before and after 
successive spawning seasons. Plaice show an ability to return over much greater distances to their feeding grounds after spawning (Hunter et al. 2003, Solmundsson et al. 2005). Marine species that are estuarine spawners can also show a high fidelity for returning to their natal estuary, as shown for the weakfish Cynoscion regalis (Thorrold et al. 2001).

\section{Site fidelity and homing}

In the middle estuary, Stns T8 to T10 and T12, flounder exhibited a high site fidelity, $95 \%$ of the total estuary and sound recaptures from these stations were from the marking station. Few fish left their marking station until the start of spawning migration and then they returned to the same estuarine station after spawning. Flounder in some inshore populations also show relatively little movement away from their marking area (Vitinsh 1976).

Flounder living in the upper part of the estuary, above T12, were more mobile due to the hydrographic conditions in the upper estuary. Low river flow and high temperatures in summer can combine to cause de-oxygenation in the region of the estuary above Stn T22 so that few fish can survive. High river flows both flush flounder out of the upper reaches and remove the mud deposits that support many of their food organisms (Hartley 1940). Flounder are normally not caught at sea off Plymouth outside the spawning season, but are occasionally captured offshore in trawls after heavy rains (Hartley 1947). The water bailiff on the freshwater part of the estuary reported that all the mud at Stn T29 was removed within $24 \mathrm{~h}$ under strong flow conditions and not replaced until it was re-deposited by spring tides when river flows were low, as much as $1 \mathrm{~m}$ of mud then being deposited per tide (J. Adams pers. comm.). Under spate conditions, most of the upper estuary flounder probably remain in the lower estuary until low river flow and spring tides restore the habitat in the upper reaches. Of the 118 out-of-position recaptures in the estuary, 21 could be explained by upper estuary fish displaced during autumn/winter, and 8 by displaced fish being marked on the lower and mid-reaches during winter and recaptured on their normal grounds during summer (Table 4). These observations would explain the finding by Hartley (1947) that small flounders tagged at Saltash (Stn T7) during winter were often found higher up the estuaries during summer. The smaller fish are most easily displaced by strong water flows. Thus, they will preferentially accumulate in the lower reaches during winter.

The situation in the upper estuary, where there is now little intertidal mudflat following canalisation
(Tamar Estuaries Consultative Forum 1999), is different to that in the middle and lower estuary, where large intertidal mudflats and inlets provide foraging areas at high tide (Hartley 1940). Comparing the ratio of adjacent stations recaptures to home station recaptures, there were 20:72 from T27 to T29, in the upper estuary, and 8:627 from T8 to T11, in the middle estuary (Table 1). A significantly higher proportion of adjacent station recaptures $(p<0.001)$ occurred in the upper estuary. The smaller intertidal feeding area probably contributes to a greater feeding movement of flounder along the estuary in this zone at high water, resulting in a greater home site longitudinal range of individual flounder in periods of low to normal river flow (Table 4). In rivers where there are no obstructions, flounder can migrate $>50 \mathrm{~km}$ into freshwater (McCurdy 1977), and it is likely that the horizontal range occupied by individual flounder in rivers is much greater than that in tidal estuaries.

The presence of a resident population of flounder within the sound was supported by a limited amount of marking there. Recaptures of estuary-marked fish in the sound suggest that at least some of the sound population is recruited from the estuary.

The displacement studies within the estuary and Plymouth Sound showed that, of 681 flounder displaced to different sites, 114 of the recaptures were from the original marking site and only 2 were from the release site (Table 5). The latter could be due to the fish being caught at Stn T2 during their return from spawning, on the way to their home station.

Studies of other flatfish also show a high degree of site fidelity, at least during some stages of their life cycle. Juvenile plaice have a high a long-shore site fidelity, $78 \%$ remaining within $100 \mathrm{~m}$ of the marking site from one day to the next and returning rapidly when displaced by $100 \mathrm{~m}$ or more (Burrows et al. 2004). Juvenile plaice can return to their nursery ground after a displacement of $3.5 \mathrm{~km}$ offshore (Riley 1973). In contrast adult plaice only have a high fidelity for feeding areas covering many kilometres (Hunter et al. 2003, Solmundsson et al. 2005).

The 87 to $97 \%$ site fidelity shown by adult flounder within the lower and middle estuary (Stns T2 to T12) over the whole marking period compares with $89 \%$ shown by juvenile Solea solea at T9 and T10 (Coggan \& Dando 1988). The majority (90 to $98 \%$ ) of young Pseudopleuronectes americanus were found to remain within $100 \mathrm{~m}$ of their estuarine marking site after 1 to 3 wk (Saucerman \& Deegan 1991). A very high site fidelity, in summer, was found for Fundulus heteroclitus in a tidal creek, with fish remaining within $36 \mathrm{~m}$ along one bank and returning when displaced across the creek (Lotrich 1975). Dace Leuciscus leuciscus show diel migrations between daylight shallow areas 
and night time feeding areas, returning to the same position within a few metres in each area (Clough \& Ladle 1997). Flounder show similar, albeit tidal, migrations between feeding areas on the mudflats and resting areas off the mudflats. They move onto the mudflats with the tide to feed (Hartley 1940, Wirjoatmodjo \& Pitcher 1984, Raffaelli et al. 1990) and return to deep water, off the mud bank, at low tide. Since stop-netters, working in the inlet off Stn T9, captured marked fish on one day, but then captured no flounder on subsequent days, it is likely that most of the flounder have a fidelity to small foraging areas in the intertidal region.

The mechanism by which these fish species locate their home area after displacement is not known, although olfactory and magnetic cues have been suggested. Olfaction would not apply to long-range homing, such as for the fish released at Poole. If flounder can detect the earth's magnetic field, then this ability is weak. Many of the fish moved east, not towards Plymouth. The rapid deposition of sediment washed out of the upper estuary by high water flows would be expected to disrupt olfactory homing ability in the middle estuary, where site fidelity remained high throughout the year.

Acknowledgements. I thank the crews of RL 'Gammarus', RL 'Sepia' and RV 'Squilla' for assistance with sampling. R. Coggan, C. Kilvington, M. I. Liddicoat, R. Ling, J. Mavin and J. Silvani are gratefully acknowledged for all their assistance in the estuary and at sea. The staff of the MAFF Fisheries Offices, particularly at Brixham and Plymouth, and W. Beaumont of the FBA River Laboratory at East Stoke are thanked for their assistance in distributing reward notices and receiving marked fish. S. Bray and the Cornwall River Authority kindly provided data on the water flow rates over the weir at Gunnislake. The present study was partly financed by the UK Natural Environment Research Council through the Marine Biological Association and by an Esmee Fairbairn Foundation Award EN/06-2816 for research on the migratory fishes of the United Kingdom. The manuscript was improved by the helpful comments of 4 reviewers.

\section{LITERATURE CITED}

Andersen KP, Bagge O (1963) The benefit of plaice transplantation as estimated by tagging experiments. Int Comm NW Atl Fish Spec Publ 4:164-171

> Beaumont WRC, Mann RHK (1984) The age, growth and diet of a freshwater population of the flounder, Platichthys flesus (L), in southern England. J Fish Biol 25:607-616

Berrebi P, Agnese JF, Vianet R (1983) Structure genetique des flets (Platichthys flesus, Téléostéen, Pleuronectidae). Bases biologiques de l'aquaculture. Montpellier 12-16 decembre 1983. IFREMER (Inst Fr Rech Exploit Mer) Actes Colloq 1:363-372

Berrebi P, Vianet R, Agnese JF, Quignard JP, Pasteur N (1985) Variabilite genetique et morphologique de quelques populations de flets: Platichthys flesus flesus des Cotes Mediterraneennes et Atlantiques Francaise. Biochem Syst Ecol 13:55-61
Borsa P, Blanquer A, Berrebi P (1997) Genetic structure of the flounders Platichthys flesus and P. stellatus at different geographic scales. Mar Biol 129:233-246

Bos AR (1999) Tidal transport of flounder larvae (Pleuronectes flesus) in the Elbe River, Germany. Arch Fish Mar Res 47: 47-60

Burrows MT, Gibson RN, Robb L, Maclean A (2004) Alongshore dispersal and site fidelity of juvenile plaice from tagging and transplants. J Fish Biol 65:620-634

Cameron P, Berg J, Dethlefsen V, von Westernhagen H (1992) Developmental defects in pelagic embryos of several flatfish species in the southern North Sea. Neth J Sea Res 29:239-256

Clough S, Ladle M (1997) Diel migration and site fidelity in a stream-dwelling cyprinid, Leuciscus leuciscus. J Fish Biol 50:1117-1119

Coggan RAC, Dando PR (1988) Movements of juvenile Dover sole, Solea solea (L), in the Tamar estuary, south-western England. J Fish Biol 33:177-184

Dando PR (1984) Reproduction in estuarine fish. In: Potts GW, Wooton RJ (eds) Fish reproduction, strategies and tactics. Academic Press, London, p 150-170

> Dando PR, Ling R (1980) Freeze-branding of flatfish: flounder, Platichthys flesus, and plaice, Pleuronectes platessa. J Mar Biol Assoc UK 60:741-748

Draganik B, Ivanow S, Tomczak M, Maksimov BY, PsutyLipska I (2007) Status of exploited Baltic flounder stocks in the southern Baltic area (ICES SD 26). Oceanol Hydrobiol Stud 36:47-64

> Florin AB, Höglund J (2008) Population structure of flounder (Platichthys flesus) in the Baltic Sea: differences among demersal and pelagic spawners. Heredity 101:27-38

Galleguillos RA, Ward RD (1982) Genetic and morphological divergence between populations of the flatfish Platichthys flesus (L.) (Pleuronectidae). Biol J Linn Soc 17:395-408

> Hartley PHT (1940) The Saltash tuck-net fishery and the ecology of some estuarine fishes. J Mar Biol Assoc UK 24:1-68

> Hartley PHT (1947) Observations on flounders Pleuronectes flesus L. marked in the estuaries of the Tamar and Lynher. J Mar Biol Assoc UK 27:53-64

> Hartley PHT, Spooner GM (1938) The ecology of the Tamar estuary. I. Introduction. J Mar Biol Assoc UK 22:501-508

> Hemmer-Hansen J, Nielsen EE, Frydenberg J, Loeschcke V (2007a) Adaptive divergence in a high gene flow environment: Hsc70 variation in the European flounder (Platichthys flesus L.). Heredity 99:592-600

> Hemmer-Hansen J, Nielsen EE, Grønkjaer P, Loeschcke V (2007b) Evolutionary mechanisms shaping the genetic population structure of marine fishes: lessons from the European flounder (Platichthys flesus L.). Mol Ecol 16: 3104-3118

Holt EWA (1897) Record book of fish catches, including many in the Tamar. National Marine Biological Library, Plymouth

Hunter E, Metcalfe JD, Reynolds JD (2003) Migration route and spawning area fidelity by North Sea plaice. Proc Biol Sci 270:2097-2103

Hutchinson S, Hawkins LE (1993) The migration and growth of O-group flounders Pleuronectes flesus in mixohaline conditions. J Fish Biol 43:325-328

International Baltic Sea Fisheries Commission (1998) Baltic 21 Series No. 4/98. Sector report on fisheries. Contribution to 'Baltic 21' Agenda 21 for the Baltic Sea Region. International Baltic Sea Fisheries Commission, Warsaw

International Council for the Exploration of the Sea (1965) Report of the working group on sole. ICES Coop Res Rep $5: 3-14$ 
Kerstan M (1991) The importance of rivers as nursery grounds for 0- and 1-group flounder (Platichthys flesus L.) in comparison to the Wadden Sea. Neth J Sea Res 27:353-366

Larsen PF, Nielsen EE, Williams TD, Hemmer-Hansen J and others (2007) Adaptive differences in gene expression in European flounder (Platichthys flesus). Mol Ecol 16: 4674-4683

Larsen PF, Nielsen EE, Williams TD, Loeschcke V (2008) Intraspecific variation in expression of candidate genes for osmoregulation, heme biosynthesis and stress resistance suggests local adaptation in European flounder (Platichthys flesus). Heredity 101:247-259

Lotrich VA (1975) Summer home range and movements of Fundulus heteroclitus (Pisces: Cyprinodontidae) in a tidal creek. Ecology 56:191-198

Maitland PS, Herdson D (2009) Key to the marine and freshwater fishes of Britain and Ireland. Environment Agency, Bristol

Marine Biological Association of the United Kingdom (1973) Report of the council 1972/3. J Mar Biol Assoc UK 53: 991-1026

McCurdy WJ (1977) A record of flounder, Platichthys flesus L., in Loch Neagh. Ir Nat J 19:122

McHugh M, Sims DW, Partridge JC, Genner MJ (2011) A century later: long-term change of an inshore temperate marine fish assemblage. J Sea Res 65:187-194

Microsoft Corporation (2010) Fisher's Exact Test calculator for $2 \times 2$ contingency tables. Available at: http://research. microsoft.com/en-us/um/redmond/projects/mscompbio/ FisherExactTest/ (accessed on 21 April 2011)

Möller H, Dieckwisch B (1991) Larval fish production in the tidal River Elbe 1985-1986. J Fish Biol 38:829-838

Norman JR (1934) A systematic monograph of the flatfishes (Heterosomata). British Museum (Natural History), London

Percival E (1929) A report on the fauna of the River Tamar and the River Lynher. J Mar Biol Assoc UK 16:81-108

Raffaelli D, Richner H, Summers R, Northcott S (1990) Tidal migrations in the flounder. Mar Behav Physiol 16:249-260

Riley J (1973) Movements of 0-group plaice Pleuronectes platessa L. as shown by latex tagging. J Fish Biol 5: 323-343

Saucerman SE, Deegan LA (1991) Lateral and cross-channel movement of young-of-the-year winter flounder (Pseudopleuronectes americanus) in Waquoit Bay, Massachusetts.

Submitted: April 27, 2010; Accepted: March 3, 2011
Estuaries 14:440-446

Sims DW, Wearmouth VJ, Genner MJ, Southward AJ, Hawkins SJ (2004) Low-temperature-driven early spawning migration of a temperate marine fish. J Anim Ecol 73:333-341

Solmundsson J, Palsson J, Karlsson H (2005) Fidelity of mature Icelandic plaice (Pleuronectes platessa) to spawning and feeding grounds. ICES J Mar Sci 62:189-200

Summers RW (1979) Life cycle and population ecology of the flounder Platichthys flesus (L.) in the Ythan estuary, Scotland. J Nat Hist 13:703-723

Tamar Estuaries Consultative Forum (1999) Map 1 Upper Tamar: an audit of coastal change in the Tamar Estuaries 1999. Available at: www.plymouth.gov.uk/tecfdocumentsandpublications (accessed on 21 April 2011)

Thorrold SR, Latkoczy C, Swart PK, Jones CM (2001) Natal homing in a marine fish metapopulation. Science 291: 297-299

van der Land MA (1991) Distribution of flatfish eggs in the 1989 egg surveys in the southern North Sea and mortality of plaice and sole eggs. Neth J Sea Res 27:277-286

van der Veer HW, Bergman MJN, Dapper R, Witte JIJ (1991) Population dynamics of an intertidal O-group flounder Platichthys flesus population in the western Dutch Wadden Sea. Mar Ecol Prog Ser 73:141-148

Vitinsh M (1976) Some regularities of flounder (Platichthys flesus L.) distribution and migrations in the eastern and north-eastern Baltic. Rybokhoz Issledovaniya SSSR GDR Bas Balt Mor 14:39-48 (in Russian)

Wheeler A (1978) The fishes of the British Isles and northwest Europe. Macmillan, London

Wheeler A (1979) The tidal Thames. The history of a river and its fishes. F. Routledge \& P. Keegan, London

Wilson DP (1939) Seasonal variations in the fat content of the flounder, Pleuronectes flesus L. J Mar Biol Assoc UK 23: 361-379

Wirjoatmodjo S, Pitcher TJ (1984) Flounders follow the tides to feed: evidence from ultrasonic tracking in an estuary. Estuar Coast Shelf Sci 19:231-241

Yasuda T, Kawabe R, Takahashi R, Murata H, Kurita Y, Nakatsuka N, Arai N (2010) Habitat shifts in relation to the reproduction of Japanese flounder Paralichthys olivaceus revealed by a depth-temperature data logger. J Exp Mar Biol Ecol 385:50-58

Proofs received from author(s): April 25, 2011 